\title{
Role of Model Essays in Developing Students Writing Skills in Malaysian Schools: A Review of Literature
}

\author{
Sarala @ Thulasi A/P Palpanadan \\ Faculty of Education, Universiti Teknologi Malaysia \\ saralathulasi@hotmail.com \\ Fauziah Bte Ismail \\ Language Academy, Universiti Teknologi Malaysia \\ fauziahismail@utm.my \\ Abdul Rahim Bin Salam \\ Language Academy, Universiti Teknologi Malaysia \\ m-arahim@utm.my
}

Doi:10.5901/mjss.2015.v6n2s1p56

\begin{abstract}
This study explored teachers' beliefs and their experiences about language writing teaching in the context of Malaysian schools. More specifically, the paper discuses different perspectives that how model essay as a technique can be used to develop students' writing skills effectively. Studies reveal that students in Malaysian classrooms have poor writing skills. The problem is that teaching of writing has been largely based on productive method which produces negative results for the Malaysian graduates. In recent times, a paradigm shift has occurred in language teaching and learning and teachers are turning towards process techniques for teaching writing skills. Despite this new motivation, research shows that teachers in Malaysian school resort to the traditional product approach. The main aim of this paper is to investigate into this phenomena that why teachers still follow the product approach for writing instruction. To investigate into this problem, the paper used systematic review of literature as a technique. The findings revealed that teachers in Malaysian schools use the product method. The research discovered several reasons behind this practice: more number of classes, motivation to cover the syllabus on time and teachers find it easier to provide feedback to students as it saves their time. On the basis of this review, the paper recommends that for effective writing, teachers must provide students with new strategies such as creative writing, self-evaluation and critical analysis practices. To achieve this goal, the use paper recommends the use of model essays as starting point to learn how to write.
\end{abstract}

Keywords: Model essay, product writing, process writing, Malaysian classrooms, poor writing skills,

\section{Introduction}

English language is one of the most spoken languages in the world (Akinwamide, 2012). In Malaysia, English is taught as a second language (L2) in primary and secondary schools. Much attention is paid by the Malaysian government towards the low language skills among Malaysian students (Normazidah, Koo, and Hazita, 2012). Researchers have indicated many reasons for this situation. For example, Malaysian students are found to have writing skill deficiencies (Nesamalar, Saratha, and Teh, 2001). This situation has created concerns among both academicians and parents. At school level, writing component is given much credit (marks) for evaluation. According to scholars, writing skills help students at later stages of education especially at the higher level as well as in professional life (David, 2001; Cai, 2001; Dovey, 2010).

Teachers find teaching of writing more difficult than teaching other language skills such as speaking, listening and reading (Akinwamide, 2012). Despite this issue, other writers argue that teachers' practices and instruction deeply affect students' writing skills (Sahin, Bullock, and Stables, 2002). Studies have revealed that for the development of students' writing skills, teachers need to provide clear writing instructions for students during a writing activity (David, 1991; Hu, 2003). For this purpose, teachers need to be trained in writing. They must possess writing knowledge and skills to guide and motivate students for practicing writing skills. One of the ways for teachers to improve their writing skills is that they can adopt variety of approaches of English language (Kong, 2005). 
Much research was carried out on L1 composition pedagogy in the 1960s, 1970s and 1980s (Hossein and Nasrin, 2012). As a result, many teaching approaches in L2 writing grew out of the L1 writing practices. Currently, literature does not refer to any comprehensive theories in L2 writing (Silva, 1990). However, among the prevailing language approaches two approaches are very popular: product and process approaches. These approaches are mostly found to be practised by language teachers in their teaching of writing in ESL classrooms (Badger and White, 2000). Interestingly, in Malaysian language classrooms, these two writing approaches have gone through different phases (Ghabool et al., 2012).

\section{Objectives}

The main aim of this paper is to analyze the functions of product approach, especially the use of model essays in teaching writing skills to students. This review is important because it reflects on how the approach is conceptualised in writing instructions in the classrooms while raising questions about the prevailing low writing skills among Malaysian students. Based on this rationale, this paper attempts to achieve the following objectives:

- To find out the causes of poor writing skills among students in Malaysian schools.

- To evaluate the role of model essays as a tool to improve writing skills.

- To suggest ways in utilizing model essays to develop writing skills in Malaysian schools.

\section{Methodology}

To achieve the above objectives, an extensive review of existing literature was used as a technique to explore the problem and to suggest solutions. The review of literature is a technique of evaluation of already existing research work on the issue under investigation (Fraenkal, Wallen \& Hyun, 1993). The main aim of review is to provide, evaluate, analyze and synthesize the knowledge and ideas shared by other studies on the problem under study. For this study too, the researchers used review of literature as a technique to address the research objectives of the paper. Review approach as a research tool has been extensively used by researchers and writers in social science research (Gay, Mills \& Airasian, 2009).

\section{Product Approach in Teaching Writing}

Product approach is one of the classical methods of language learning. It is also known as Model Approach (Akinwamide, 2012). Before the 1970s, product approach was a popular method and was widely used as writing instruction. Its main focus was on very rigid text features of model texts. Most importance was given to rules of grammar in writing teaching and learning (Nystrand, 2006). However, later on, this method faced much opposition due to its rigidity less utility as a method of language learning. Consequently, language specialists began to pay attention to individual learning and the writing processes. In 1970s and 1980s, educators and researchers started taking more interest in process writing method. As a result, process writing approaches were employed in language classrooms with the attention to content prior to form (Raimes, 1991). Nevertheless, later on, the popularity of this approach decreased due to its constraints such as time factor, workload related to marking the drafts, teacher's belief, and linguistic accuracies and so on (Chow, 2007; Pour-Mohammadi, Abidin \& Fong, 2012). This situation motivated teachers to choose product approach. Researchers have argued that product approach helps teachers in introducing different types of essays that help them to cover the syllabus on time. This situation motivated the teachers slowly towards the product approach in the ESL writing instruction in the 1990s (Chow, 2007).

Researchers explain that product approach encourages students to produce an end product which may be identical to a model essay or the essay provided by the teachers (McCrimmon, 1994; Deng, 2003). The basic aim is about providing linguistic knowledge to the students rather than improving their writing skills (Pincas, 1982a). In turn, students imitate the sentences to get familiarity with the content, copy and finally transform the models into a new essay to be as perfect as the one that they have imitated by focusing on the correct language (Mourtaga, 2004).

Students are required to submit their essays to the teacher (evaluator) to be marked. After doing the necessary corrections students resubmit their essays to the teachers. The product approach encourages students to imitate models to get familiarity with the content, copy and transform the models given by the teachers in the form of sample essays. Students may practice some of these simple sentences and produce a piece of writing identical to the model essay given. Thus, product approach attracts students' attention to imitate a model by focusing on the correct language which is not very useful (Murray, 1980; Steele, 1992).

Literature has indicated that product approach stresses on the content of the text as well as the score obtained 
(Hasan and Akhand, 2010). In this approach, students are required to finish texts in terms of language accuracy. In this type of approach, the teachers provide feedback on the basis of grammar and lexical errors. In short, the writing tasks become decontextualized further neglecting the contexts and audience. There are four stages in the Product Approach Model (Steele, 2004:1). Figure 1 below depicts the stages involved:

Figure 1: Product Approach Model

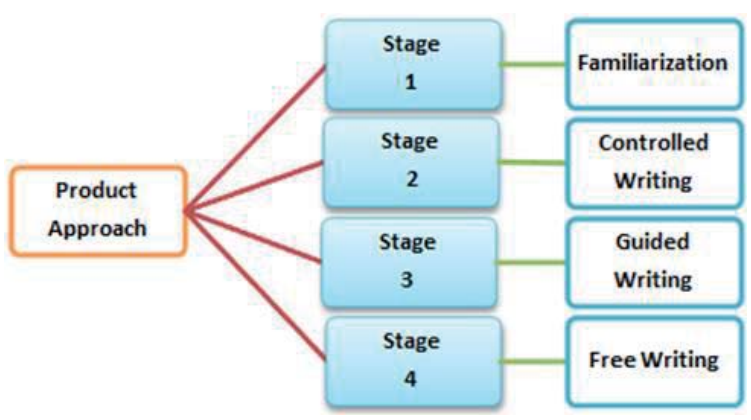

(Adapted from Steele, 2004:1)

According to Steele, (2004), there are four different stages in the product approach to teach writing. In stage one, students are required to study the model texts followed by highlighting the features of the genre. For example, if studying a formal letter, students' attention may be drawn to the importance of paragraphing and the language is used to make formal requests. If a student reads a story, the focus is on the techniques used to make the story interesting, and students do controlled practice of the highlighted features of the text separately. While studying a formal letter, they may be asked to practise the language for making formal requests, for example, practising the 'I would be grateful if you would...' structure. In stage three, students organize the ideas. Those who favour this approach believe that the organization of ideas is more important than the ideas themselves and as important as the control of language. In the fourth stage, students choose from the choice of comparable writing tasks to show that they can be fluent and competent users of the language. Students use the skills, structures and vocabulary to produce the product individually.

\section{Merit and Demerits of Product Approach}

Writers have argued that using model essay to teach writing is useful. Whereas, others argue that model essays bring serious repercussions to the students in terms of the quality of students' better writing skills (Ackerman, 1993; Ferris, 2007). Research studies have shown that models are helpful for students to write essays but sometimes it may hinder students from achieving better writing abilities (Nazim \& Ahmad, 2012). Studies have reported that many teachers find it comfortable to practice or adapt product approaches due to several reasons. First, teacher's response plays a key role in helping students to identify their mistakes and rectify them. This is the only way to reach students due to less time availability for teachers to individually coach the students due to large number of students per classroom as well as more teaching period in Malaysian schools. Second, students find opportunity to correct their mistakes and learn to use correct grammar and sentence structure by looking at the teacher's marking. This will help teachers to ensure that students do not learn erroneous structures. This method works effectively when the teachers mark the essays as soon as possible before the students forget what they have written after some time (Musa, Lie \& Azman, 2012).

The product approach which was adopted to solve teachers' problems in the writing instruction has created other challenges in the teaching of writing. In a study conducted by Wingate (2012) students found the model texts very useful in providing information prior to their writing activities. Wingate further suggested that analysis of model text is a good starting point for writing instruction followed by the development of critical perspective. In another study, Paul Escholoz (1980) noted that models inhibit writers and make to become mere copiers. Others established that in product writing, students tend to become dependent writers when each time they are provided with model essays for reference and the subsequent activities are not paid attention. Apparently, there is a call to scrutinize the original philosophy of the product approach (naturally involves 4 stages) and the way it is implemented whether or not all the stages are practiced chronologically in the classrooms. The current practice in schools which focuses on copying sample essay seems to take over all the stages involved in the approach. As a result, the students fail to assimilate critical thinking into their creative 
writing when they tend to memorize and replicate a model (Hasan \& Akhand, 2010). This attitude can lead to plagiarist tendencies among learners. In some cases, they may not feel guilty about taking others' work without making sufficient acknowledgement.

Today, a profound stress placed on examinations as a benchmark for measuring academic achievements of students (Ko0, 2008). This trend has motivated teachers to instruct students to write with accurate language and structures as this area has become the main focus in the assessment of students' writing (Pour-Mohammadi, Abidin \& Fong). Consequently, teachers neglect the communicative aspects of the language by giving attention to the teaching of grammar (Musa, Lie \& Azman, 2012). Furthermore, most ESL teachers who assume themselves as language teachers rather than writing teachers tend to utilize writing lessons as a platform to practice grammar and other linguistic features of the subject (Zamel, 1985). Under such a situation, students become operators of the learnt language structure and teachers become the editors or proof readers who are interested in accuracy of language rather than skills improvement that eventually reduces students' creativity in writing activities (Luchini, 2003).

According to some researchers, teachers feel comfortable with the way they are trained and decide to adopt and adapt writing lessons according to the way they learnt writing in school, teachers' training college or university. Highlighting this situation, Chow (2007) describes that most of the ESL teachers in Malaysian schools today learn to write in the traditional product-oriented ways which is focused on linguistic features rather than language skills. This is seen as the key to effective writing, as a result, students tend to write what they think their teachers would consent and deprive themselves from voicing out their own expression (Tan \& Miller, 2008).

Models are the skeleton or illustrations of parts that help students especially novice writers to begin writing by assisting them with unclear expression and the skills required to establish an assignment but the models can lead students astray if one is not aware of the limits (Macbeth, 2010). The findings of this study revealed three types of false provisions: the introductory to an essay, the thesis connection and structure. First, students who followed models could not write 'interesting' introduction for their own essays. The models were required to be used as a guide for students to progress toward independent writing which was misused by some students. Second, students who followed the models' thesis statement without paying attention to the meaning found themselves defending similarities and differences that opposed their own opinion. Some students who copied from the thesis sentences faced problems with supporting points which they left unattended or repeated the points in the thesis statement. The students then realized that models are cases where they should not be used word for word (2010). Third, some students imitated insufficient model structures as the way to support a claim such as using a quotation or paraphrasing. However, some good students managed to rectify the false promises of the models knowing that different assignments require different ways of writing. Macbeth (2010) suggested that students need to be alerted about the false provisions so that they may understand the necessary adaptations or changes which were needed in the models before starting the writing activity.

Models provide powerful input to students as they are selected examples of good writing (Watson, 1982). The writer further argues that the effectiveness of producing another piece of writing by studying and scrutinizing the models which was hoped to support students' understanding of how good writing is done. In this regard, many issues have been highlighted by the writer about using models in writing class. For example, First, that models can be very useful for new writers as it can provide them with 'maximum support and reassurance' but the models can turn out to be 'depressingly artificial' as students tend to follow the same sentence structure even after passing the elementary level (1982). The writer further explains that using authentic materials as models for creating writing motivations among students can be more useful rather than imitating the models. For this purpose, models can be beneficial if treated as 'a resource rather that an ideal' (1982:12). There is a need to compare their works with the model where the model is introduced in the later part of the process of writing instruction (Chow, 2007). This activity is helpful for students to enable them to participate in the writing activity more meaningfully rather than just producing another identical essay like the models (Tan \& Miller, 2008).

There is a continuous debate over which approach is more useful for students. But at the same time, there is a pressuring need to address the current problem on how to help ESL students to improve in English language proficiency and language use (Ghabool, Edwina, and Hossein, 2012). In Malaysian context, students of mixed ability are found. So, extensively depending only on one approach in writing instructions seems difficult in the ESL classrooms (Tan \& Miller, 2007). Therefore, focusing on the end product at the cost of neglecting the process purpose of writing will not help the students to become effective writers.

\section{Conclusion}

On the basis of the above study it can be concluded that the models that are used to teach writing need to be compatible 
to the students' needs and proficiency level to make the process writing more effective. The study further concludes that the use of models in teaching writing can be effective, because, the model essays may be used as a starting point for students to learn how to write. Last but not least, there is a perception that those students who obtain good grades in public examinations do not know how to write effectively. They struggle when they enter tertiary education or their professional work place. It can be concluded that teachers must adopt innovative writing techniques such as creative writing, self-evaluation and critical analysis to develop and guide students learn effective writing skills in the form of independent writers. To achieve this goal, the attention should not only be focused on the quantity of A's obtained by students but it should be also on the quality of the ' $A$ ' produced for the development of the country and nation.

\section{References}

Ackerman, J. M. (1993). The promise of writing to learn. Written Communication, 10, 334-370.

Akinwamide, T.K. (2012). The Influence of Process Approach on English as Second Language Students' Performances in Essay Writing. $E L T, 5(3), 16-29$.

Badger, R. \& White, G. (2000). A process genre approach to teaching writing. ELT Journal, 52(2), 153-160.

Cai, L. (2001). Application of Product Teaching on College English Writing. Journal of the Foreign Language World.

Chow, V.F.T. (2007). The Effects of the process-genre approach to writing instruction on the expository essays of ESL students in a Malaysian secondary school. Unpublished doctoral dissertation. Kuala Lumpur, Malaysia.

David., N.(2001). Second English Teaching and Learning. Beijing: Foreign Language Teaching and Research Press.

David, N. (1991). Language Teaching Methodology. A Textbook for Teachers. Prentice Hall.

Deng, L. (2003). Hints of Systematic Research of Process Teaching to College English Teaching. Foreign Language Teaching.

Dovey, T. (2010). Facilitating writing from sources: A focus on both process and product. Journal of English for Academic Purposes, (9), $45-60$

Ferris, D. (2007). Preparing teachers to respond to student writing. Journal of Second Language Writing, (6) 165-193

Fraenkel, J. R., Wallen, N. E., \& Hyun, H. H. (1993). How to design and evaluate research in education (Vol. 7). New York: McGraw-Hill.

Gay, L. R., Mills, G. E., \& Airasian, P. W. (2009). Educational research: Competencies for analysis and applications (ed.). Columbus, $\mathrm{OH}$ : Pearson

Ghabool, N., Mariann, E. M., \& Seyyed Hossein, K. (2012). Investigating Malaysian ESL Students' Writing Problems on Conventions, Punctuation, and Language Use at Secondary School Level. Journal of Studies in Education, 2(3), 130-143.

Hasan, M.K., \& Akhand, M.M. (2010). Approaches to Writing in EFL/ESL context: Balancing Product and Process in Writing Class at Tertiary Level. Journal of NELTA. 15(1-2), 77-88.

Hashemnezhad, H., \& Hashemnezhad, N.(2012). A Comparative Study of Product, Process, and Post-process Approaches in Iranian EFL Students' Writing Skill. Journal of Language Teaching and Research, 3(4), 722-729.

Hunter, W.J., \& Begoray, J. (1990). A framework for the activities involved in the Writing Process. The Writing Notebook. 7(3), 1-5.

$\mathrm{Hu}, \mathrm{X}$. (2003). Application of Process Teaching. Journal of the Foreign Language World.

Kaur, N. (2006). Non-autonomy and low-English proficiency among Malaysian Students: Insights from multiple perspectives.

Kong, C. (2005). Review on the Writing Theories of Foreign language in China. Foreign Languages' Teaching and Research

Leng, N. K., \& Roslina Abdul Aziz. (Eds.), English in the Malaysian context (21-34). Shah Alam: University Publication Centre (UPENA) UiTM

Lie, K. Y. (2008). Language, culture and literacy: Meaning-making in global context. Bangi: Penerbit UKM.

Luchini, P.L. (2003). Writing Skill Teaching: A New Perspective. The Linguistic Association of Korea Journal, 11(3), 123-143.

McCrimmon, J. (1994). Writing with a Purpose. Houghton Mifflin co

Mourtaga, K. (2004). Investigating Writing Problems among Palestinian Students: Studying English as a Foreign Language,

Bloomington, Indiana: AuthorHouse

Musa, N. C., Lie, K. Y., \& Azman, H. (2012). Exploring English language learning and teaching in Malaysia. GEMA: Online Journal of Language Studies, 12(1), 35-51.

Macbeth, K. (2010).Deliberate false provisions: The use and usefulness of models in learning academic writing. Journal of Second Language Writing. 19(2010), 33-48.

Nazim, M., \& Ahmad, J. (2012). Developing Writing Skills: A Practical Remedy of Common Writing Problems among Students of Writing Skills Courses at Preparatory Year. Journal of Language in Indi, 12(3), 348-360.

Nesamalar C., Saratha S. \& Teh, S. C. (2001). ELT methodology: Principles and practice. Selangor: Penerbit Fajar Bakti.

Nystrand, M. (2006). The social and historical context for wrotong research. In C.Macarthur, S Graham \& J. Fitzgerald (Eds.), Handbook of Writing Research. New York: Guilford Press

Pincas, A. (1982a). Teaching English Writing. London: Macmillian.

Pour-Mohammadi, M., Abidin, M. J. Z., \& Fong, C. L. (2012). The Effect of Process Writing Practice on the Writing Quality of Form One Students: A Case Study. Asian Social Science, 8(3), 88-99

Raimes, A. (1991). Out of the woods: Emerging traditions in the teaching of writing. TESOL Quarterly, 25, 407-430.

Sahin, C., Bullock, K. \& Stables, A. (2002). Teachers' Beliefs and Practices in relation to their Beliefs about Questioning at Key Stage 2. Educational Studies. 28(4), 371-384. 
Silva, T. (1990). Second Language composition instruction: developments, issues, and directions in ESL. In B, Kroll (Eds.), Second Language Writing. Research insights for the language classroom (10-23). Cambridge: Cambridge University Press.

Steele, V. (2004). Product and process writing. Retrieved on 10 Mac 2013 from http://www.teachingenglish.english.org.uk/think/write/ approaches.html

Steele, V.(1992). Product and Process Writing: A Comparison. Rowley: Newbury House.

Tan, E.K., \& Miller, J. (2008). Writing in English in Malaysian High Schools: The Discourse of Examinations, England: Routledge.

Watson, C. B. (1982). The Use and Abuse of Models in the ESL Writing Class. TESOL Quarterly, 16(1), 5-14.

Wingate, U. (2012). Using Academic Literacies and genre-based models for academic writing instruction: A 'literacy' journey. Journal of English for Academic Purposes 11, 26-37

Zamel, V. (1985). Responding to student writing. TESOL Quarterly, 19(1), 79-101. 